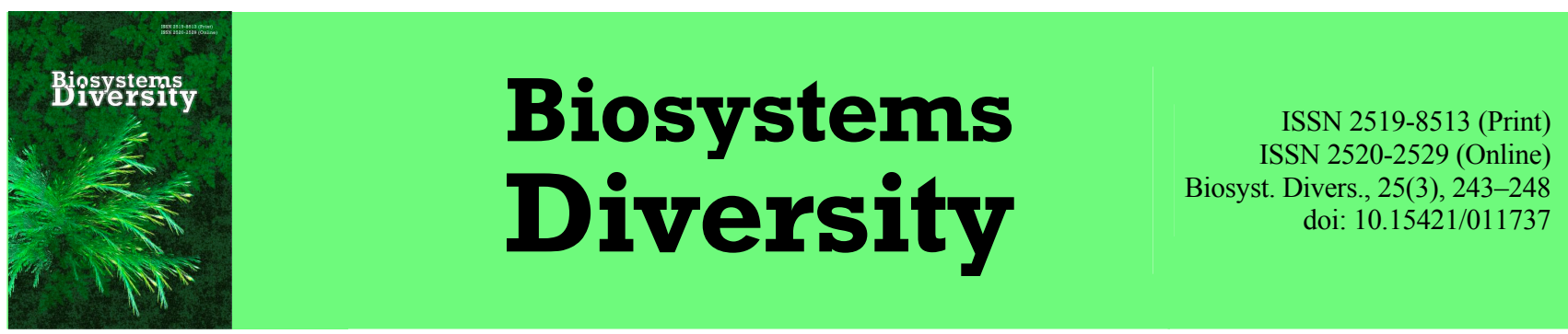

\title{
The dynamics of the population and peculiarities of the morphometric structure of Melophagus ovinus (Diptera, Hippoboscidae) in Ukraine
}

\author{
V. A. Yevstafyeva*, T. A. Sharavara*, V. V. Melnychuk*, O. V. Sirenko*, \\ O. B. Prijma**, L. V. Nagorna***, N. S. Kanivets*, Y. O. Borodai* \\ *Poltava State Agrarian Academy, Poltava, Ukraine \\ **Lviv National University of Veterinary Medicine and Biotechnologies named after S. Z. Gzhytskyj, Lviv, Ukraine \\ ***Sumy National Agrarian University, Sumy, Ukraine
}

Article info

Received 09.06.2017

Received in revised form 17.07.2017

Accepted 19.07.2017

Poltava State Agrarian Academy

Skovorody Str., 1/3,

Poltava, 36003, Ukraine.

Tel.:+38-050-183-78-78

E-mail:evstva@ukr.net

Lviv National University of Veterinary Medicine and Biotechnologies named after

S. Z. Gzhytskyj, Pekarska Str., 50, Lviv, 79000, Ukraine.

Sumy National Agrarian University, G. Kondrateva Str. 160, Sumy, 40021, Ukraine.

\author{
Yevstafyeva, V. A., Sharavara, T. A., Melnychuk, V. V., Sirenko, O. V., Prijma, O. B., Nagorna, L. V., Kanivets, N. S., \& \\ Borodai, $Y$. O. (2017). The dynamics of the population and peculiarities of the morphometric structure of Melophagus \\ ovinus (Diptera, Hippoboscidae) in Ukraine. Biosystems Diversity, 25(3), 243-248. doi:10.15421/011737
}

The indices of the Melophagus ovinus (Linnaeus, 1758) population in Ukraine, and also the peculiarities of morphological and metric structure of the insects' body at all the stages of their development within the conditions of the surveyed region were investigated. New data on morphometric differential signs of sexually mature males and females of sheep bloodsuckers were obtained. It was established that M. ovinus are significantly widespread in Poltava and Zaporizhzhia regions, and they parasitize $26.1 \%$ of the examined sheep stock with the infection intensity of $92.7 \pm$ 1.4 specimens and abundance -24.7 specimens on one animal. The dynamics of $M$. ovinus population at different stages of development was characterized by the highest abundance of sexually mature males (11.1 specimens) and females ( 8.9 specimens). The given index concerning pupae and larvae was considerably lower (4.2 and 0.5 specimens on one animal). It was found that post-embryonic and adult development stages of M. ovinus differ in their metric indices.The length and width of the pupae were $17.4 \%$ and $13.2 \%$ larger than those of the larvae. The sizes of males and females relative to the indices of body length, the length and width of head, thoracic, and abdominal segments, the length of maxillary palpus and the length and width of the proboscis in fact differ in their values. The differential morphological species signs of M. ovinus are the form and location of oculi, antennae, the structure of the head segment of the body, and the mouthparts, and of sexual dimorphism - the distance from the caudal segment of the copulatory apparatus to the rear of the insect's last abdominal segment.

Keywords: bloodsucking insect; sheep; index of abundance; intensity of infestation; differential signs

\section{Introduction}

Insects and invertebrates close to them, represent the object of entomologyand are a wonderful group of animals. Among all the living organisms, inhabiting the Earth, the insects are the first as to both the number of species and the population. The number of ecological niches, occupied by insects, is huge: they can be found on other insects, feed on live or dead plants, and parasitize on the body or in the internal organs of higher animals. Often, a species has its own specific niche (Ross et al., 1982; Speight et al., 1999; Schowalter, 2000).

The body structure of insects, their tissues, and organs is often not less complex in their own way than those of higher vertebrates, though the body size of many adult insects reaches only $1-2 \mathrm{~mm}$. The high biological lability of insects has enabled them to adapt to existence under various conditions. This peculiarity has facilitated the intensive transition of insects to parasitism. Some of them have become obligate plant parasites, others have adapted to parasitizing on animals. In the majority of cases, the transformation of adult stage insects into animal parasites was connected with the emergence of hematophagy (Chernyshov, 1996; Adams, 1999; Lehane, 2005; Korzh et al., 2009). One representative of the last mentioned group of insects is Melophagus ovinus (Linnaeus, 1758), which parasitize on sheep, causing the disease melophagosis (Small, 2005; Mulugeta et al., 2010; Kumsa et al., 2012; Martinkovic et al., 2012; Amare et al., 2013).

Researchers have noted the considerable spreading and adaptation of the sheep bloodsucking insect population to the climatic condi- tions in the USA (Bulman and Lamberti, 2001; Scasta and Koepke, 2016), Chile (Alvarez et al., 2010), Ethiopia (Wall, 2007; Chanie et al., 2010; Berhanu et al., 2011; Kumsa et al., 2014), the Republic of Argentina (Olaechea et al., 2006; Escribano et al., 2012), Iraq (Zangana et al., 2013), Brazil (Costa et al., 1983) and Kazakhstan (Doszhanov, 1975), where the prevalence of infection fluctuated from 1.2 to $100.0 \%$.

A large number of papers testify that $M$. ovinus is a widespread ectoparasite across most of the territory of the Russian Federation (Domatskaia, 1974; Migunov and Timofeev, 1999). For example, parasitization by sheep bloodsucking insects has been found on the territory of 10 regions of the Republic of Bashkortostan; prevalence of infection indices varied from $29 \%$ to $100 \%$, and intensity - from $12.1 \pm 2.2$ to $495.7 \pm 12.2$ insects on an animal (Abdullin, 2014).

Such high population indices of M. ovinus can be explained by the peculiarity of their structure, which was formed in the process of adaptation to parasitizing on sheep. Researchers point out, that as a result of metamorphosis, M. ovinus, transformed into a wingless insect, and the structure of its body assists in better feeding, moving, fixing on wool, and reproduction, which considerably raises their survival prospects under such conditions of parasitism (Hutson, 1984; Mullen and Durden, 2009). Nevertheless, the data concerning the separate aspects of morphology and metric differential signs of M. ovinus are outdated, sometimes contradictory, and they only incompletely disclose the peculiarities of their structure at different biological stages of the insects' development. For example, some 
authors mention, that the body length of imago insects varies from 4 to $7 \mathrm{~mm}$, and after sucking blood and the presence of larvae in the females' gonads, their length increases to $10 \mathrm{~mm}$ (Vorobiov et al., 1966). Other authors confirm, that the length of sexually mature M. ovinus is between 4-6 mm (Luedke et al., 1965) or may fluctuate from 2.5 to $10.0 \mathrm{~mm}$ (Narchuk, 2003). At the same time, some researchers have found that the body length of M. ovinus is 6-7 mm (Sewell and Brockesby, 1990).

It is proven that M. ovinus is a permanent species specific ectoparasite, which belongs to the category of viviparous insects, and the cycle of its development takes place through complete transformation, including the following phases: larvae, pupae, and imago (Wall and Shearer, 1997). Not enough attention is paid to the peculiarities of the morphometric structure of $M$. ovinus pre-adult stages in the scientific literature. It is known that the larvae of $M$. ovinus are rather large, immobile, of white colour, round form, and have the length up to $3.5 \mathrm{~mm}$. After 6-12 hours the larvae on the animal's body transform into pupae, their chitinous covering becomes harder and turns a chestnut-brown colour, their length is $3-4 \mathrm{~mm}$ ( $2 / 3$ of imago length) (Suarez et al., 2007; Olaechea, 2009).

The aim of the this article is to determine the indices of population number of $M$. ovinus at different stages of their development under the conditions of the Forest-Steppe and Steppe zones of Ukraine, and also to establish the differential morphometric signs of adult and pre-adult forms of insects - hematophags.

\section{Materials and methods}

The research was conducted during 2015-2017 on the basis of the research laboratory of the Department of Parasitology and Veterinary-Sanitary Expert Examination of the Faculty of Veterinary Medicine at Poltava State Agrarian Academy. The population indices of $M$. ovinus were studied on the basis of agricultural enterprises, private holdings, and sheep farms in the Forest-Steppe and Steppe zones of Ukraine (Veselivka, Berdiansk, Zaporizhzhia, Melitopol, Novomykolaivka, Orikhivka, Tokmak districts of Zaporizhzhia region; Poltava, Chutove, Zinkiv, Dykanka, Novi Sanzhary districts of Poltava region). While examining the sheep stock the main indices of the M. ovinus population were the prevalence of infection, infection intensity, and abundance (Ripolovskyi and Yuskiv, 2010). The insects were caught and collected at all the stages of their development using fingers and anatomical forceps by the complete surveying of the animals' hair covering (Tretiakov et al., 2006). Bloodsucking insects were identified with the help of an identification guide (Ler, 2001). In all, 5084 sheep were examined.

The identification of differential morphological and metric parameters of the M. ovinus specimens obtained at different stages of their development was conducted taking into account the peculiarities of the structure of the head, thoracic, abdominal body segments, mouthparts, and oculi of males and females, and also the length and width of their larvae and pupae.

With the aim of measuring the bloodsucking insects' metric characteristics the ImageJ for Windows ${ }^{\circledR}$ (Version 2.00) software in interactive conditions was used and also a ${ }^{\times} 16$ object-glass and a ${ }^{\times} 10$ eyepiece. The projection of the ruler points of the ocular-micrometer on the ruler of the object-micrometer was used for calibrating the images' analyzer (the micrometers were in the set of a MicroMed microscope). Taking micro-pictures was conducted using a digital camera attached to a MicroMed 3Mpix microscope (China). The statistical processing of the experimental research results was performed using the tables of Student's t-criteria (Lapach et al., 2001).

\section{Results}

According to the results of the conducted survey, the bloodsucking insect $M$. ovinus was found to be a widespread parasitic insect on the territory of the Forest-Steppe and Steppe of Ukraine. The average prevalence of infection of sheep with M. ovinus was $26.1 \%$, infection intensity $-92.72 \pm 1.41$ specimens on an animal's body (minimal and maximal indicators fluctuated from 2 to 301 specimens). At the same time, the average abundance was 24.7 specimens on one animal.

It was determined, that within the population of M. ovinus, out of 125,701 representatives of the given species sexually mature $\hat{\sigma}-$ $44.8 \%$ (56,251 specimens) and $\circ-36.2 \%$ (45,441 specimens) prevailed. The population of pupae and larvae was less $-16.9 \%$ and $2.2 \%$ (21,269 and 27,40 specimens). The abundance was: $\delta-11.1$ specimens, +-8.9 specimens, pupae -4.2 specimens, larvae 0.5 specimens on one animal (Fig. 1).

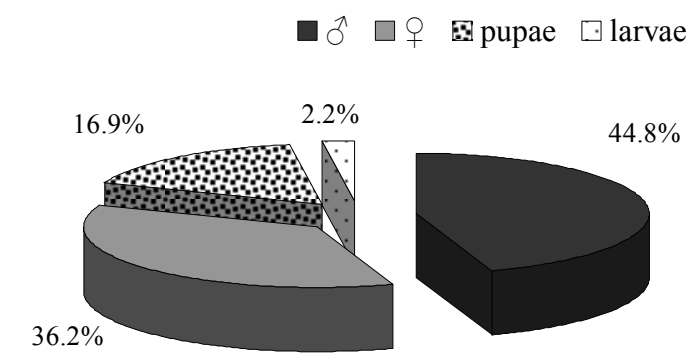

$a$

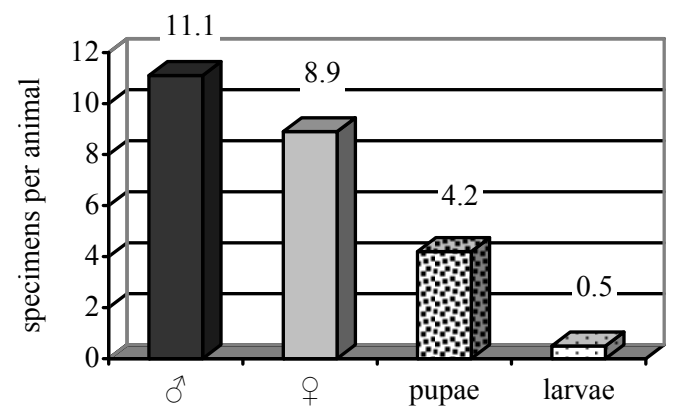

$b$

Fig 1. The indices of M. ovinus population at different stages of their development $(\mathrm{n}=125,701): a$ - percentage; $b$-abundance

As a result of the conducted research, it was established that the M. ovinus population is represented by four biological forms: $\lambda, \rho$, larvae, and pupae, which have characteristic differential morphological and metric characteristics (size, form, and body structure) (Fig. 2, Table 1).

For example, the larvae had an oval-elongated form, milkywhite colouring, and soft chitinous covering. Their body length and width, on average was $3.14 \pm 0.02 \mathrm{~mm}$ (and fluctuated from 3.0 to $3.5 \mathrm{~mm}$ ) and $1.64 \pm 0.02 \mathrm{~mm}$ (and fluctuated from 1.4 to $1.8 \mathrm{~mm}$ ). The pupae were of oval form and brown colouring, and their chitinous covering was much harder than that of the larvae. It was proven that their length and width was in fact larger, respectively, by $17.4 \%(3.80 \pm 0.06 \mathrm{~mm}, \mathrm{P}<0.001)$ and by $13.2 \%(1.89 \pm$ $0.02 \mathrm{~mm}, \mathrm{P}<0.001)$, than those of the larvae.

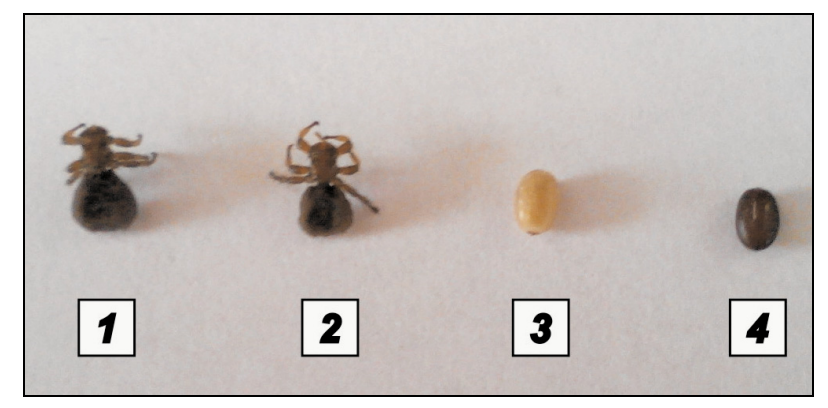

Fig. 2. M. ovinus: $1-q ; 2-\hat{O} ; 3-$ larva; 4 - pupa

Sexually mature males and females of $M$. ovinus visually do not differ from each other. The peculiarities of the head segment structure of the body of this species were registered by morphologi- 
cal investigations. The head of the insects is prognostically localized relative to the thoracic and abdominal segments, which is characteristic of parasitic insects, their mouthparts are directed forward. The head is flattened, insignificantly pressed into the thoracic segment, and consists of the following segments: vertex, frons, genae, postgenae, subgenae, occiput, and also contains the mouthparts, oculi, and antennae (feelers). The chitinous covering of the head of M. ovinus is covered with short, stiff bristles (Fig. 3). It is characteristic that the clypeus is greatly displaced, it is of insignificant size, and directed forward together with the mouthparts.

Table 1

Metric parameters of post-embryonic development stages of $M$. ovinus, $\mathrm{n}=50$

\begin{tabular}{|c|c|c|c|c|}
\hline \multirow{2}{*}{\multicolumn{2}{|c|}{ Indices }} & \multicolumn{3}{|c|}{ Sizes, mm } \\
\hline & & $\mathrm{M} \pm \mathrm{m}$ & $\min$ & $\max$ \\
\hline \multirow{2}{*}{ Larvae } & length & $3.14 \pm 0.02$ & 3.0 & 3.5 \\
\hline & width & $1.64 \pm 0.02$ & 1.4 & 1.8 \\
\hline \multirow{2}{*}{ Pupae } & length & $3.80 \pm 0.06^{* * *}$ & 3.0 & 5.0 \\
\hline & width & $1.89 \pm 0.02 * * *$ & 1.7 & 2.2 \\
\hline
\end{tabular}

Note: $* * *-\mathrm{P}<0.001$ relative to the larva indices.

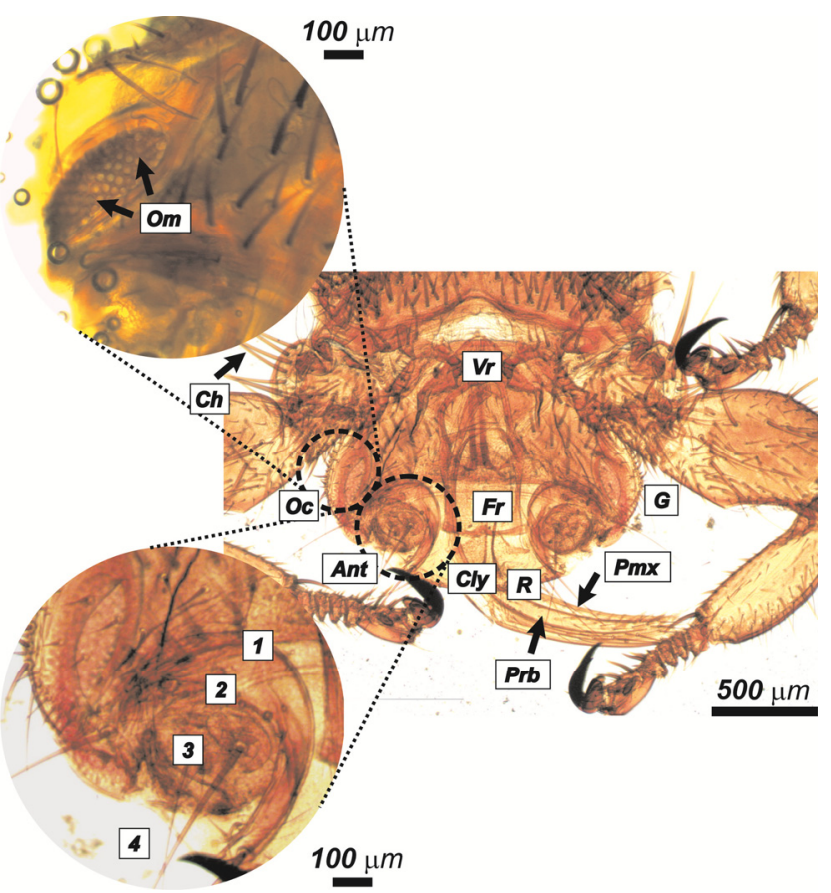

Fig. 3. The morphological structure of the head segment of the M. ovinus imago body $\left({ }^{\times} 40,{ }^{\times} 100\right): V r-$ vertex, $F r$ - frons,

$G$ - gena, Ant - antennae, $P m x$ - palpus maxillaries, $C l y$ - clypeus,

$O c$ - oculus, $\mathrm{Om}$ - ommatidia, $\mathrm{Ch}$ - chetoids, $\mathrm{Prb}$ - proboscis,

$R$-rostrum; 1 - frontal antennal segment (scapus), 2 - the second antennal segment (stalk of antenna), 3 - the third antennal segment (cilium), 4 - bristles

The differential morphological sign of $M$. ovinus adult forms is the form and localization of ommatea and antennae. The ommatea are partially reduced to narrow lengthwise stripes, they are poorly noticeable and localized on the head sides behind the antennae. M. ovinus have short antennae, consisting of three segments (scapus, the stalk of antenna, and cilium); they are submerged in their own fossae, and externally look like one-segment. Nevertheless, their first antennal segment (scapus) is blended with the head capsule, the second antennal segment (the stalk of the antenna) has a deep cavity, where the third antennal segment (silium) is submerged. Only its top is visible outside looking like short bristles. The antennae are large, and they are localized on the frontal rear of the insect head segment.

The mouthpart of M. ovinus is directed forward, it is turgid, not retracted, and is adapted to bloodsucking; it is represented by the glossinoid proboscis of boring-sucking type (Fig. 4). It is composed of: the rostrum (containing the clypeus), gaustellum (consisting of prementum (labium), hypopharynx, labrum, labellum, and palpus maxillaries. The labrum and labium form the labial groove, and at the rear segment of the proboscis they overlay each other and, in fact, they represent a tube. The chitinous covering of the palpus maxillaries contains short hairs.

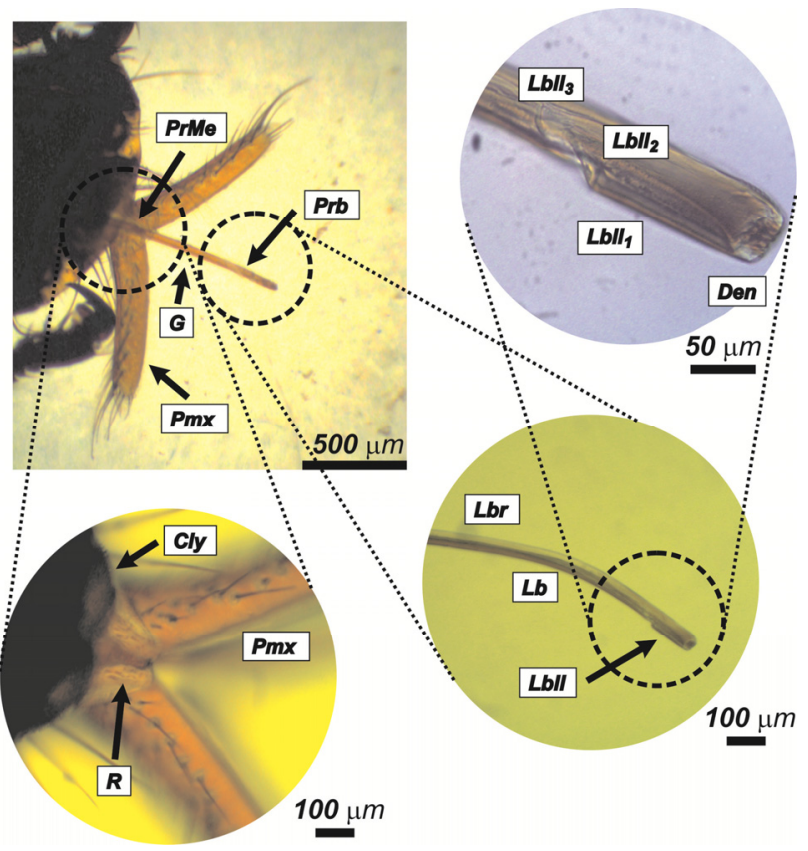

Fig. 4. The morphological structure of the mouthparts of imago M. ovinus $\left({ }^{\times} 40,{ }^{\times} 100,{ }^{\times} 400\right)$ : PrMe - prementum (part of the labium), $\mathrm{Lbll}$ - labellum, $\mathrm{Lbll}_{1}, \mathrm{Lbll}_{2}, \mathrm{Lbll}_{3}$ - the appendages of the labial plate, $G$ - gaustellum, $L b r$ - labrum, $P m x$ - palpus maxillaries, $C l y$ - clypeus, $L b$ - labium Denti, $\operatorname{Pr} b$ - proboscis, $R$ - rostrum

There is a small groove, containing the hypopharynx inside, in the middle of the labial groove. The groove and the small groove consist of thick and dense chitin. At the state of rest, the external part of the labellum or outer labial plate (Lbll) is visible on the proboscis. It is rounded at the distal end, and at the proximal one it is stretched into three large appendages $\left(\mathrm{Lbll}_{1}, \mathrm{Lbll}_{2}, \mathrm{Lbll}_{3}\right)$. The right and the left labial plates are immovably joined to each other along the abdominal line. Longitudinal furrows with denti, used by the bloodsucking insects to bore the skin of the animal, are localized on the top of the proboscis of the frontal rear of the labial plate.

The new data on the peculiarities of the morphometric body structure of adult $q$ and $\sigma^{\lambda}$ M. ovinus were obtained as a result of the research conducted (Table 2). Thus, the body length of $q$ is $12.6 \%(6.19 \pm 0.07 \mathrm{~mm}, \mathrm{P}<0.001)$ greater than that of $\delta(5.41 \pm$ $0.06 \mathrm{~mm})$. The head section of the 9 body is $8.1 \%(1.23 \pm 0.02 \mathrm{~mm}$, $\mathrm{P}<0.01)$ longer and $6.8 \%(1.51 \pm 0.02 \mathrm{~mm}, \mathrm{P}<0.001)$ narrower, than that of $\delta(1.13 \pm 0.02$ and $1.62 \pm 0.02 \mathrm{~mm})$. The thoracic section of the $q$ body turned out to be $7.4 \%(1.63 \pm 0.02 \mathrm{~mm}, \mathrm{P}<$ $0.001)$ shorter and $14.5 \%(1.72 \pm 0.02 \mathrm{~mm}, \mathrm{P}<0.001)$ broader than that of $\delta(1.76 \pm 0.02$ and $1.47 \pm 0.02 \mathrm{~mm})$. At the same time, the abdominal region of the $O$ body was $14.8 \%(3.58 \pm 0.02 \mathrm{~mm}, \mathrm{P}<$ $0.001)$ longer and $13.5 \%(3.33 \pm 0.02 \mathrm{~mm}, \mathrm{P}<0.001)$ broader than that of $\bar{\partial}(3.05 \pm 0.042$ and $2.88 \pm 0.03 \mathrm{~mm})$.

The sizes of the ommatea also turned out to be different in $\widehat{\delta}$ and $q$. In $q$ they were $2.5 \%(351.91 \pm 1.34 \mu \mathrm{m}, \mathrm{P}<0.001)$ longer and $11.7 \%(98.14 \pm 0.64 \mu \mathrm{m}, \mathrm{P}<0.001)$ narrower that those of $\sigma^{\lambda}$ $(343.06 \pm 1.74$ and $111.88 \pm 1.88 \mu \mathrm{m})$. Metric parameters of the mouthparts were characterized by larger values concerning the length of palpus maxillaries (by $3.6 \%, \mathrm{P}<0.001$ ) and proboscis (by $11.4 \%$ and $10.9 \%, \mathrm{P}<0.001)$ in 9 than in $\delta(893.42 \pm 4.20$ and $168.47 \pm 3.57 \mu \mathrm{m}$ and $845.48 \pm 2.19$ and $38.55 \pm 0.16 \mu \mathrm{m})$. 
Table 2

Metric parameters of the adult stages

of $M$. ovinus development, $\mathrm{n}=50$

\begin{tabular}{|c|c|c|c|c|}
\hline \multirow{2}{*}{ Indices } & \multicolumn{2}{|l|}{9} & \multicolumn{2}{|c|}{$\hat{0}$} \\
\hline & $\mathrm{M} \pm \mathrm{m}$ & $\min -\max$ & $\mathrm{M} \pm \mathrm{m}$ & $\min -\max$ \\
\hline $\begin{array}{l}\text { Body length, } \\
\mathrm{mm}\end{array}$ & $6.19 \pm 0.07 * * *$ & $5.0-7.0$ & $5.41 \pm 0.06$ & $4.5-6.5$ \\
\hline \multicolumn{5}{|c|}{ Head segment } \\
\hline length, $\mathrm{mm}$ & $1.23 \pm 0.02 * *$ & $1,0-1.4$ & $1.13 \pm 0.02$ & $1.0-1.3$ \\
\hline width, $\mathrm{n}$ & $1.51 \pm 0.02 * * *$ & $1.2-1.7$ & $1.62 \pm 0.02$ & $1.4-1.8$ \\
\hline \multicolumn{5}{|c|}{ Ommatea } \\
\hline length, $\mu \mathrm{m}$ & $351.91 \pm 1.34 * * *$ & $330.2-368.6$ & $343.06 \pm 1.74$ & $318.1-367.8$ \\
\hline width, $\mu \mathrm{m}$ & $98.14 \pm 0.64^{* * *}$ & $89.3-109.5$ & $111.88 \pm 1.88$ & $97.1-134.4$ \\
\hline \multicolumn{5}{|c|}{ Mouthparts, including: } \\
\hline \multicolumn{5}{|c|}{ Palpus maxillaries } \\
\hline length, & $927.24 \pm 3.56^{* * *}$ & $878.8-984.5$ & $893.42 \pm 4.20$ & $837.1-933.4$ \\
\hline width, $\mu \mathrm{m}$ & $174.36 \pm 3.43$ & $131.8-213.6$ & $168.47 \pm 3.57$ & $121.8-213.6$ \\
\hline \multicolumn{5}{|c|}{ Proboscis } \\
\hline length, $\mu \mathrm{m}$ & $954.37 \pm 2.46^{* * *}$ & $911.4-976.0$ & $845.48 \pm 2.19$ & $812.2-871.3$ \\
\hline width, $\mu \mathrm{m}$ & $43.27 \pm 0.08^{* * *}$ & $42.1-44.1$ & $38.55 \pm 0.16$ & $36.1-40.9$ \\
\hline \multicolumn{5}{|c|}{ Thoracic segment } \\
\hline length, $\mathrm{mm}$ & $1.63 \pm 0.02^{* * *}$ & $1.5-1.8$ & $1.76 \pm 0.02$ & $1.5-2.0$ \\
\hline width, mm & $1.72 \pm 0.02^{* * *}$ & $1.3-1.9$ & $1.47 \pm 0.02$ & $1.3-1.7$ \\
\hline \multicolumn{5}{|c|}{ Abdominal segment } \\
\hline length, $\mathrm{mm}$ & $3.58 \pm 0.02 * * *$ & $3.3-3.8$ & $3.05 \pm 0.04$ & $2.7-3.5$ \\
\hline width, mm & $3.33 \pm 0.02 * * *$ & $3.0-3.5$ & $2.88 \pm 0.03$ & $2.6-3.2$ \\
\hline
\end{tabular}

Note: $* *-\mathrm{P}<0.01 ; * * *-\mathrm{P}<0.001$ relative to indices in $\widehat{\jmath}$.

Our own research confirmed that sexual dimorphism is inherent to this species of ectoparasite. The main morphological sign distinguishing $q$ and $\delta$ of $M$. ovinus is the presence of external genitals on the abdominal genital segments' sterna. Nevertheless, because of feeding on blood, the insects' abdomen becomes of dark-brown, almost black colour, and it is difficult to see through. As a result, it is difficult to identify the peculiarities of the sex appendages structure to determine the sex of the insects during microscopic examination. That is why we suggested determining the distance from the localization of the external genitals to the last abdominal segment, which turned out to be in fact different in $\rho$ and $\hat{\partial}$ (Table 3, Fig. 5). Thus, the space, mentioned above, is considerably longer in males than in females. The average length in males is $128.07 \pm 2.24 \mu \mathrm{m}$ (fluctuating from 104.4 to $161.9 \mu \mathrm{m}$ ). The space from the caudal segment of the copulatory apparatus to the rear of the last abdominal segment in females is considerably less ( 3.2 times, $\mathrm{P}<0.001)$ and it is $40.14 \pm 0.58 \mu \mathrm{m}$, on the average (fluctuating from 33.1 to $48.5 \mu \mathrm{m}$ ). So, using sexual dimorphism metrical indices of the adult forms of $M$. ovinus males and females provides clear differentiation of the insects' sex, and also enables us to prognosticate the rate of increase in the population of the parasitic insects.

Table 3

Differential diagnostics of the signs

of $M$. ovinus imago sexual dimorphism, $\mathrm{M} \pm \mathrm{m}, \mathrm{n}=50$

\begin{tabular}{|c|c|c|c|}
\hline \multirow[t]{2}{*}{ M. ovinus } & \multicolumn{3}{|c|}{$\begin{array}{l}\text { The distance from the external genitals } \\
\text { to the last abdominal segment, } \mu \mathrm{m}\end{array}$} \\
\hline & $\mathrm{M} \pm \mathrm{m}$ & $\min$ & $\max$ \\
\hline$\overline{0}$ & $128.07 \pm 2.24 * * *$ & 104.4 & 161.9 \\
\hline 우 & $40.14 \pm 0.58$ & 33.1 & 48.5 \\
\hline
\end{tabular}

Note: $* * *-\mathrm{P}<0.001$ relative to 9 index.

\section{Discussion}

As a result of the conducted research, it was revealed that M. ovinus is a specific species of parasitic insect, which is considerably widespread on the territory of the Forest-Steppe and Steppe of Ukraine, in particular, in Poltava and Zaporizhzhia regions. The infestation prevalence among sheep reaches $26.1 \%$, and the indices of infection intensity and abundance were, on average, $92.72 \pm 1.41$ and 24.7 specimens on one animal. According to the scientific sources, M. ovinus has a wide range, it is adapted to various climatic conditions and is found in the regions where sheep are reared (Alvarez et al., 2010; Escribano et al., 2012; Zangana et al., 2013; Abdullin, 2014; Seyoum et al., 2015; Eshetu et al., 2017). In Ukraine, only scattered reports have been devoted to the distribution of M. ovinus, for example information about its outbreak on a farm in Kharkiv region, where goats and sheep are kept together. The prevalence of $M$. ovinus infestation in the surveyed sheep was $65.4 \%$ while the infection intensity was $118.4 \pm 12.7$ specimens per animal (Byrka and Mazannyi, 2015).

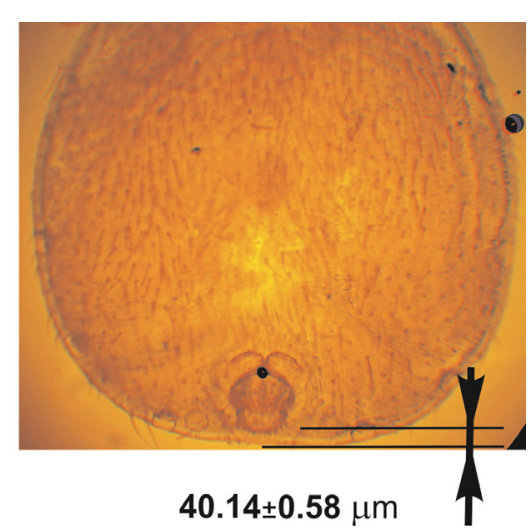

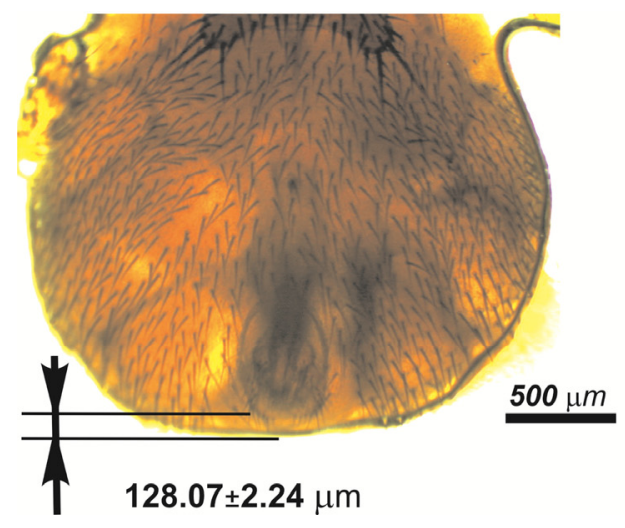

ㅇ

Fig. 5. Differential morphometric signs of M. ovinus sexual dimorphism $\left({ }^{\times} 40\right)$

We obtained new data concerning the dynamics of the $M$. ovinus population at different stages of their development. The males and females had the highest abundance within the population (11.1 and 8.9 specimens), the number of pupae and larvae was lower (4.2 and 0.5 specimens on one animal). Such dynamics can be explained by the biological peculiarities of the parasite. It is known that longevity of the males is shorter than that of the females, which is why the males must be more numerous; because larvae turn into pupae on an animal's body very quickly, their number may be less (Lewis, 1997; Bulman and Lamberti, 2001; Suarez et al., 2007; Olaechea, 2009).

The differential morphological signs of $M$. ovinus body structure at different stages of their post-embryonic and adult stages of deve- lopment, confirmed by metric characteristics, were identified with the help of the conducted research. The body length and width of the M. ovinus larvae obtained were $3.14 \pm 0.02$ and $1.64 \pm 0.02 \mathrm{~mm}$, on average. At the same time, the length and width of the pupaes' body were respectively $17.4 \%(3.80 \pm 0.06 \mathrm{~mm}, \mathrm{P}<0.001)$ and $13.2 \%$ $(1.89 \pm 0.02 \mathrm{~mm}, \mathrm{P}<0.001)$ larger than those of larvae, which proves their growth and development not only relative to the morphological, but also to metric restructuring. New data were obtained concerning the morphometric characteristics of the males' and females' body structure, which are different and prove the peculiarities of the insects' sexual dimorphism. The female body length turned out to be in fact larger (by $12.6 \%, \mathrm{P}<0.001$ ), than that of the males. The M. ovinus 
female head is longer and narrower than the male head, the thoracic section is shorter and wider, and the abdomen is longer and wider, which, in our opinion, is connected with the formation and development of the larva in the sexual organs of the female, and this, in its own turn, requires a certain ratio between the width and length of its body sections. It was also found that the sizes of the female palpus maxillaries and proboscis are in fact larger (by 3.6-11.4\%, P <0.001) than those of the males. In our opinion, this is connected with the adaptation of the females to the ability for better feeding because of the necessity of impregnating, feeding, and reproducing larvae.

It was found that the peculiarities of the differential, morphological structure of this species of insect are the following: the absence of wings, the ability to move in the wool, and also the form and localization of ommatea, antennae, the structure of the proboscis. There are separate reports, which confirm the research conducted by us concerning the structure of the boring type mouthparts of $M$. ovinus, the presence of denti on the proboscis, and also its adaptation to hematophagy (Nelson and Petrunia, 1969). The peculiarities of the sensor structure of the antennae of $M$. ovinus, which also have a specific structure, were described (Zhang et al., 2015).

We were the first to suggest a method of differential diagnostics for male and female $M$. ovinus, which is based on the metric determining of the space from the caudal part of the copulatory apparatus to the rear of the insect's last abdominal segment. This index is considerably less in the females $(3.2$ times less, $\mathrm{P}<0.001$ ) compared to the analogous index of the males.

\section{Conclusion}

The results of the survey of $M$. ovinus population indices show that on the territory of the Forest-Steppe and Steppe of Ukraine the insects parasitize $26.1 \%$ of sheep, with the infection intensity and abundance of $92.72 \pm 1.41$ and 24.7 specimens on a single animal. Adult stage forms - males and females (44.8\% and $36.2 \%)$. prevail within the population of the given species. The adaptability to parasitizing animals is characterized by the peculiarities of the differential morphological structure of this species; the main characteristics are the form and localization of the ommatea, antennae, and also the structure of the proboscis. As a matter of fact, determining the space from the caudal part of the copulatory apparatus to the rear of the insect's last abdominal segment is one of the signs of M. ovinus sexual dimorphism. The metric parameters of the post-embryonic stages of $M$. ovinus development are characterized by increase in the width and length of the pupae by $13.2-17.4 \%$ comparative to the larvae sizes, and as far as adult stages are concerned, the male body is larger than that of the female, and also there is reliable difference in metrical indices concerning the length and width of the head, thoracic, and abdominal sections, and also the length and width of palpus maxillaries and proboscis.

\section{References}

Abdullin, S. M. (2014). Jekstensivnost' i intensivnost' melofagoznoj invazii v uslovijah Respubliki Bashkortostan [The prevalence and intensity of melophagosis invasion under the conditions of the Republic of Bashkortostan]. Modern Achievements of Veterinary Medicine and Biology into Agricultural Production. Bashkirskii State Agrarian University, Ufa (in Russian).

Adams, T. S. (1999). Hematophagy and hormone release. Annals of the Entomological Society of America, 92, 1-13.

Alvarez, J. F., Leal, J., Dalmazzo, C., \& Muller, C. (2010). Melophagus ovinus (sheep keds) control program in the Magallanes Region, Chile. World Buiatrics Congress, Chile.

Amare, S., Asfaw, Y., \& Tolossa, Y. H. (2013). Ectoparasites of sheep and goats in North-West Amhara Regional State, Ethiopia. Ethiopian Veterinary Journal, 17(1), 55-67.

Berhanu, W., Negussie, H., Alemu, S., \& Mazengia, H. (2011). Assessment on major factors that cause skin rejection at Modjo export tannery, Ethiopia. Tropical Animal Health and Production, 43(5), 989-993.

Bulman, G. M., \& Lamberti, J. C. (2001). Melophagus ovinus. AAPAVET, Buenos Aires.
Byrka, V. I., \& Mazannyi, A. V. (2015). Rasprostranenie Melophagus ovinus (Diptera: Hippoboscidae) i bor'ba s nej v neblagopoluchnom hozjajstve [Spreading of Melophagus ovinus (Diptera: Hippoboscidae) and fight against it on the unfavorable farm]. Scientific Notes of "Znak Pocheta" State Academy of Veterinary Medicine, 51(1), 174-178 (in Russian).

Chanie, M., Negash, T., \& Sirak, A. (2010). Ectoparasites are the major causes of various types of skin lesions in small ruminants in Ethiopia. Tropical Animal Health and Production, 42(6), 1103-1109.

Chernyshov, V. B. (1996). Jekologija nasekomyh [Ecology of insects]. Moscow (in Russian).

Costa, J. O., Lima, W. S., Leite, A. C. R., Guimarães, M. P., \& Torres, L. D. (1983). Melophagus ovinus e Trypanosoma (Megatrypanum) melophagium em ovinos no estado de Minas Gerais, Brasil. Memórias do Instituto Oswaldo Cruz, 78(1), 101-103.

Domatskaia, M. D. (1974). Jekstensivnost' i intensivnost' porazhenija ovec krovososkami v Tjumenskoj oblasti [Prevalence and Intensity of sheep infestation with blood-sucking insects in Tiumen Region]. The Questions of Veterinary Arakhno-Entomology, 5, 25-29 (in Russian).

Doszhanov, T. N. (1975). Muhi krovososki (Diptera, Hippoboscidae) domashnih i dikih mlekopitajushhih Kazahstana i sopredel'nyh territorii [Blood-sucking flies (Diptera, Hippoboscidae) of domestic and wild mammals of Kazakhstan and adjoining territories]. Problems of Parasitology, 1, 156-157 (in Russian).

Escribano, C., Olmedo, E., Pantoja, C., Disalvo, V., Canalis, V., Marquez, P., Sleiman, M., Narbaiza, C., \& Gea, P. D. (2012). Informe preliminar del primer relevamiento de Melophagus ovinus en el ganado lanar de Tierra del Fuego. INTA EEA Santa Cruz, Argentina.

Eshetu, A., Ayele, T., Mengistu, S., \& Belina, D. (2017). Prevalence of Melophagus ovinus and Bovicola ovis infestation in sheep in Wogera District, North Gondar Zone, Ethiopia. Journal of Veterinary Science and Technology, 8(3), 1-5.

Hutson, A. M. (1984). Keds, flat-flies and bat-flies. Diptera, Hippoboscidae and Nycteribidae. Handbooks for the Identification of British Insects, 10(7), 19.

Korzh, O. P., Lebedeva, N. I., Voronova, N. V., \& Horban, V. V. (2009). Osnovy parazytologiji (Parazitizm jak biologichne javishhe) [The fundamentals of parasitology (Parasitism as biological phenomena)]. University Book, Sumy (in Russian).

Kumsa, B., Beyecha, K., \& Geloye, M. (2012). Ectoparasites of sheep in three agro-ecological zones in Central Oromia, Ethiopia. Onderstepoort Journal of Veterinary Research, 79(1), 1-7.

Kumsa, B., Parola, P., Raoult, D., \& Socolovschi, C. (2014). Bartonella melophagi in Melophagus ovinus (sheep ked) collected from sheep in northern Oromia, Ethiopia. Comparative Immunology, Microbiology and Infectious Diseases, 37(1), 69-76.

Lapach, S. N., Chubenko, A. V., \& Babich, P. N. (2001). Statisticheskie metody v mediko-biologicheskih issledovanijah $\mathrm{s}$ ispol'zovaniem Excel [Statistical methods in medical and biological research using Excel]. Morion, Kyiv (in Russian).

Legg, D. E., Kumar, R., Watson, D. W., \& Lloyd, J. E. (1991). Seasonal movement and spatial distribution of the sheep ked (Diptera: Hippoboscidae) on Wyoming lambs. Journal of Economic Entomology, 84(5), 1532-1539.

Lehane, M. (2005). The biology of blood-sucking in insects, second edition. Cambridge University Press, New York.

Ler, P. A. (2001). Opredelitel' nasekomyh Dal'nego Vostoka Rossii. Dvukrylye i blohi: Semejstvo Hippoboscidae - krovososki [Determining book of insects of the far east of Russia. Wto-winged and fleas: Hippoboscidae family blood-sucking insects]. Dal'nauka, Vladivostok (in Russian).

Lewis, C. J. (1997). Treatment, prevention and control of ectoparasitic diseases of sheep. Journal of the Royal Agricultural Society of England, 158, 40-53.

Luedke, A. J., Jochim, M. M., \& Bowne, J. G. (1965). Preliminary bluetongue transmission with the sheep ked Melophagus ovinus (L.). Canadian Journal of Comparative Medicine and Veterinary Science, 29(9), 229-231.

Martinkovic, F., Matanovic, K., Rodrigues, A. C., Garcia, H. A., \& Teixeira, M. M. (2012). Trypanosoma (Megatrypanum) melophagium in the sheep ked Melophagus ovinus from organic farms in Croatia: Phylogenetic inferences support restriction to sheep and sheep keds and close relationship with trypanosomes from other ruminant species. Journal of Eukaryotic Microbiology, 59(2), 134-144.

Migunov, I. M., \& Timofeev, P. V. (1999). Jentomozy ovec Zabajkal'ja [Entomoses of sheep in Zabaikalia]. East Siberian Publishing House, Chita (in Russian).

Mullen, G. R., \& Durden, L. A. (2009). Medical and veterinary entomology. Academic Press, San Diego.

Mulugeta, Y., Yacob, H. T., \& Ashenafi, H. (2010). Ectoparasites of small ruminants in three selected agro-ecological sites of Tigray Region, Ethiopia. Tropical Animal Health and Production, 42(6), 1219-1224.

Narchuk, E. P. (2003). Opredelitel' semejstv dvukrylyh nasekomyh fauny Rossii i sopredel'nyh stran (s kratkim obzorom semejstv mirovoj fauny) [The determining book of the family of two-winged insects of the Russian fauna and 
adjoining territories (together with the brief review of the world fauna families)]. Zoological Institute of the Russian Academy of Sciences, SaintPetersburg (in Russian).

Nelson, W. A., \& Petrunia, D. M. (1969). Melophagus ovinus: Feeding mechanism on transilluminated mouse ear. Experimental Parasitology, 26(3), 308-313.

Olaechea, F., Corley, J., Larroza, M., Raffo, F., \& Cabrera, R. (2006). Ingreso y evolución del parasitismo por Melophagus ovinus en una majada Corriedale en la Patagonia argentina. Parasitología Latinoamericana, 61, 86-89.

Olaechea, F. V. (2009). Aspectos básicos del ectoparásito más frecuente que afecta las majadas del sur patagónico, Melophagus ovinus. Veterinarios Patagóni$\cos , 2(5), 5-7$.

Ripolovskyi, O. I., \& Yuskiv, I. D. (2010). Dyplostomozy koropa v nahulnykh stavakh pivnichno-zakhidnoho peredkarpattia [Diplostomoses of carp in the ponds of the north-western prykarpathia]. Scientific Bulletin of Lviv National University of Veterinary Medicine and Biotechnologies named after S. Z. Gzhytskyj, 12(3), 197-205 (in Ukrainian).

Ross, H. H., Ross, A. C., \& Ross, R. P. J. (1982). A textbook of entomology. Wiley, New York.

Speight, M. R., Hunter, M. D., \& Watt, A. D. (1999). Ecology of insects concepts and applications. Oxford, United Kingdom.

Scasta, J. D., \& Koepke, K. (2016). Host-parasite ecology of keds (Melophagus ovinus (L.)) relative to sheep breed and age on Wyoming rangeland. Livestock Science, 189, 17-22.

Schowalter, T. D. (2000). Insect ecology - an ecosystem approach. Academic Press, California.
Sewell, M. M. H., \& Brockesby, D. W. (1990). Hand book on animal disease in the tropics. 4th Ed. Bailliere Tindall, United Kingdom.

Seyoum, Z., Tadesse, T., \& Addisu, A. (2015). Ectoparasites prevalence in smal ruminants in and around Sekela, Amhara Regional State, Northwest Ethiopia. Journal of Veterinary Medicine, 2015, 1-6.

Small, R. W. (2005). A review of Melophagus ovinus (L.), the sheep ked. Veterinary Parasitology, 130(1-2), 141-155.

Suarez, V. H., Olaechea, F. V., Rossanigo, C. E., \& Romero, J. R. (2007). Enfermedades parasitarias de los ovinos y otros rumiantes menores en el cono sur de América: Phthiriasis y melofagosis. Anguil, Argentina.

Tretiakov, A. M., Yevdokimov, P. I., \& Shabaev, V. A. (2006). Laboratornaja diagnostika parazitarnyh zabolevanij zhivotnyh [Laboratory dignostics of animal parasitic diseases]. Ulan-Ude (in Russian).

Vorobiov, M. M., Romanjuk, N. A., \& Popova, S. M. (1966). Melofagoz ovec [Sheep melophagosis]. Veterinary Medicine, 2, 56-57 (in Russian).

Wall, R., \& Shearer, D. (1997). Veterinary entomology: Arthropod ectoparasites of veterinary importance, 1st Ed. Champan and Hall, United Kingdom.

Wall, R. (2007). Ectoparasites: Future challenges in a changing world. Veterinary Parasitology, 148(1), 62-74.

Zangana, I. K., Ali, B. A., \& Naqid, I. A. (2013). Distribution of ectoparasites infested sheep and goats in Duhok Province, North Iraq. Basrah Journal of Veterinary Research, 12(1), 54-64.

Zhang. D., Liu, X. H., Li, X. Y., Cao, J., Chu, H. J., \& Li, K. (2015). Ultrastructural investigation of antennae in three cutaneous myiasis flies: Melophagus ovinus, Hippobosca equina, and Hippobosca longipennis (Diptera: Hippoboscidae). Parasitology Research, 114(5), 1887-1896. 